\title{
Obesity induces ovarian inflammation and reduces oocyte quality
}

\author{
Alexandria P Snider and Jennifer R Wood \\ Department of Animal Science, University of Nebraska-Lincoln, Lincoln, Nebraska, USA \\ Correspondence should be addressed to J R Wood; Email: jwood5@unl.edu
}

\begin{abstract}
In the United States, $36.5 \%$ of women between the ages of 20 and 39 years are obese. This obesity results in not only metabolic disorders including type II diabetes and cardiovascular disease, but also impaired female fertility. Systemic and tissue-specific chronic inflammation and oxidative stress are common characteristics of obesity. This is also true in the ovary. Several studies have demonstrated that pro-inflammatory cytokines and reactive oxygen species alter estrous cyclicity, steroidogenesis and ovulation. Inflammation and oxidative stress also impair meiotic and cytoplasmic maturation of the oocyte which reduces its developmental competence for fertilization and pre-implantation embryo development. Interestingly, there is recent evidence that obesity- and/or polycystic ovary syndrome (PCOS)-dependent changes to the gut microbiome contributes to ovarian inflammation, steroidogenesis and the expression of mRNAs in the oocyte. However, several gaps remain necessitating future studies to identify inflammation, oxidative stress and gut microbiome mechanisms that reduce ovarian function and oocyte quality.

Reproduction (2019) 158 R79-R90
\end{abstract}

\section{Introduction}

Obesity has progressed from a significant health risk to an epidemic in the United States. Obesity is defined as body mass index (BMI) greater than $30 \mathrm{~kg} / \mathrm{m}^{2}$ and in the US, 39.6 percent of adults ( $>20)$ were classified as obese in 2015-2016 (Hales et al. 2017). Reproductive age women (20-39 years) have similar obesity rates $(36.5 \%)$ compared to the general population. However, there is ethnic obesity disparity such that $55 \%$ of African American and $51 \%$ of Hispanic reproductive age women are classified as obese (Hales et al. 2017). Obesity is characterized by increased lipid storage in adipose tissue and other metabolic organs, which leads to cellular lipid toxicity, inflammation and oxidative stress. The result is development of metabolic dysfunctions like type II diabetes, cardiovascular disease and ultimately, reduced quality and quantity of life. Importantly, the percentages of obese and overweight adults are expected to rise to 50\% by 2030 (Wang et al. 2011, Finkelstein et al. 2012).

Obesity in women not only affects her metabolism but also her reproductive health. Specifically, obese women are at increased risk for ovulatory subfertility and anovulatory infertility compared to age-matched lean women (Pandey \& Bhattacharya 2010, Kumbak et al. 2012, Penzias 2012). While anovulation can be overcome with ovarian stimulation, obese women have decreased responsiveness to gonadotropins, decreased oocyte retrieval, decreased oocyte quality, reduced rates of pre-implantation embryo development and increased risk for miscarriage compared to their lean counterparts (Kumbak et al. 2012, Klenov \& Jungheim 2014, Broughton \& Moley 2017). Current research aims to define obesity-dependent mechanisms that cause these phenotypes in order to prevent or reverse female infertility.

\section{Obesity causes chronic inflammation, oxidative stress and changes to the gut microbiome}

Acute inflammation, which is triggered by tissue damage as a result of an invading pathogen or trauma, activates the release of chemokines by resident innate immune cells. These chemokines attract additional innate immune cells from the systemic circulation (Sokol \& Luster 2015). At the same time, resident and infiltrating innate immune cells produce pro-inflammatory cytokines. The cytokines initiate signaling pathways at the cellular level to stimulate expression of chemokines and cytokines as well as genes that regulate cell death, senescence and survival (Sapochnik et al. 2017, Varfolomeev \& Vucic 2018). The end result is phagocytosis of damaged tissue and subsequent secretion of anti-inflammatory cytokines that regulate wound repair and resolution of the inflammatory response. Chronic inflammation is defined as unregulated and persistent chemokine and cytokine synthesis and secretion. This can be caused by unresolved inflammation after tissue damage (Landskron et al. 2014). Alternatively, environmental pressures (e.g. 
allergens), abnormal metabolism (e.g. microbiome changes) or persistent necrotic cell death within a tissue (e.g. obese adipocyte) can induce de novo inflammatory responses (Garn et al. 2016, Kuroda \& Sakaue 2017).

In the context of obesity, increased circulating triglycerides are stored in adipocytes resulting in adipocyte hypertrophy (Ouchi et al. 2011, Engin 2017). The end result is hypoxia-induced necrosis of adipocytes and infiltration of adipose tissue with circulating macrophages and $\mathrm{T}$ helper cells due to release of monocyte chemoattractant 1 (MCP-1/CCL2) and nicotinamide phosphoribosyltransferase (NAMPT) (Ouchi et al. 2011). The macrophages subsequently secrete pro-inflammatory cytokines including tumor necrosis factor alpha (TNF- $\alpha$ ) and pro-inflammatory interleukins (ILs; e.g. IL-6). These cytokines activate the $\mathrm{NF \kappa B}$ signal transduction pathway to produce more proinflammatory cytokines (Fig. 1). Adipocytes also produce factors (adipokines, e.g. leptin and lipocalin) which upon secretion promote additional release of TNF $\alpha$ and IL-6 (Ouchi et al. 2011). Importantly, when cytokines and adipokines are released into the circulation they induce inflammatory responses in other tissues including the ovary (Ouchi et al. 2011, Nteeba et al. 2013, Wang \& Huang 2015, Xie et al. 2016).

Chronic inflammation also induces oxidative stress due to increased production of reactive oxygen species (ROS) that overwhelm the cell's antioxidant system

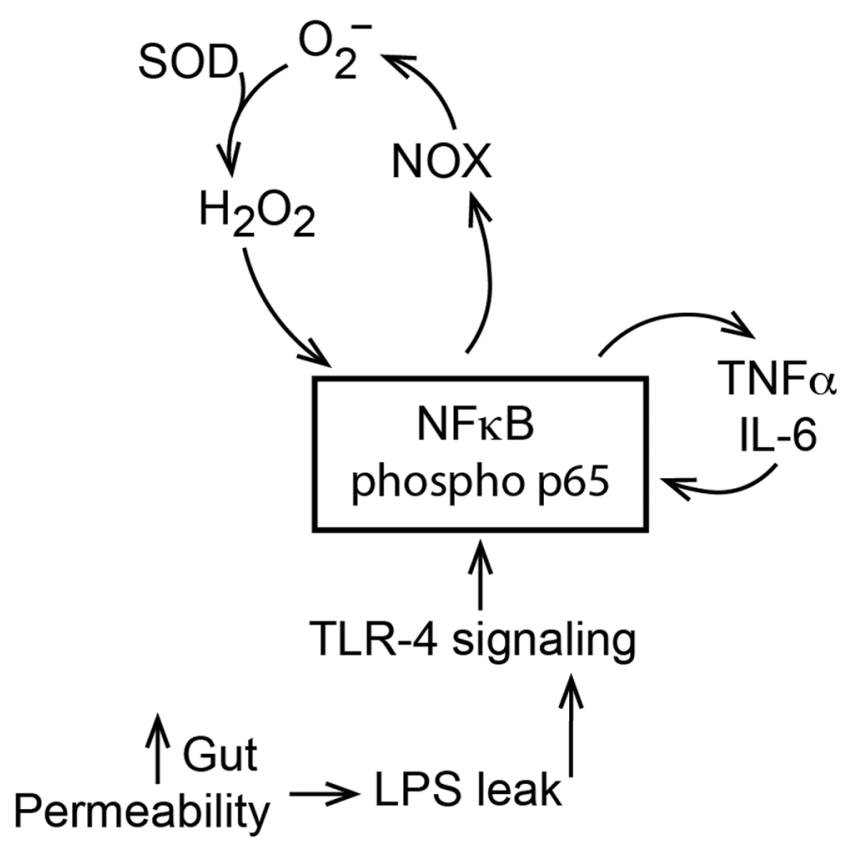

Figure 1 Schema showing relationships between increased gut permeability, inflammation and oxidative stress. $\mathrm{H}_{2} \mathrm{O}_{2}$ (hydrogen peroxide), IL-6 (interleukin-6), LPS (lipopolysaccharide), NFkB phosphor-p65 (phosphorylated p65 subunit of the nuclear factor kappa light-chain enhancer of activated B cell), NOX (NADPH oxidases), $\mathrm{O}_{2}^{-}$(superoxide), SOD (superoxide dismutase), TLR-4 (toll-like receptor-4), TNF $\alpha$ (tumor necrosis factor alpha).
(Biswas 2016, Hussain et al. 2016). The main ROS species are superoxide $\left(\mathrm{O}_{2}^{-}\right)$and hydrogen peroxide $\left(\mathrm{H}_{2} \mathrm{O}_{2}\right)$ and they are produced by multiple organelles in the cell including mitochondria, endoplasmic reticulum and peroxisomes (Brown \& Borutaite 2012, Nordgren \& Fransen 2014, Chong et al. 2017, Mailloux 2018). Inflammation-dependent increases in NFkB-p65 phosphorylation promotes expression of the redox family of NADPH oxidases (NOX) which produce $\mathrm{O}_{2}{ }^{-}$(Bedard \& Krause 2007, Lu et al. 2010). The $\mathrm{O}_{2}{ }^{-}$is subsequently converted to $\mathrm{H}_{2} \mathrm{O}_{2}$ by superoxide dismutase (SOD) (Fig. 1). The $\mathrm{H}_{2} \mathrm{O}_{2}$ can freely move from the organelle to the cytoplasm of the cell and when in the cytoplasm activates NFkB-p65 through phosphorylation (OliveiraMarques et al. 2009, Ren et al. 2015), thereby increasing the expression pro-inflammatory cytokines including TNF $\alpha$ and IL-6 (Fig. 1). Based on this interdependence of inflammation and oxidative stress, it is not surprising that obesity is also a state of chronic oxidative stress, which together contribute to the development of metabolic and neural non-communicative disease (Piya et al. 2013, Ertunc \& Hotamisligil 2016, Rimessi et al. 2016).

Over the last decade, investigators have established that symbiotic relationships between different anatomical sites (e.g. skin, colon, and vagina) and colonized microbes (microbiome), which are essential for human health (Cho \& Blaser 2012, Belizário \& Napolitano 2015). In the gut, there is a symbiotic relationship between its microbiome, the intestinal epithelia and immune system and inflammatory responses (Fig. 2). However, environmental pressures including diet and antibiotic use cause shifts in the diversity and relative abundance of the colonizing bacteria due to microenvironmental-driven changes in bacterial growth, stasis or death (Camp et al. 2009,

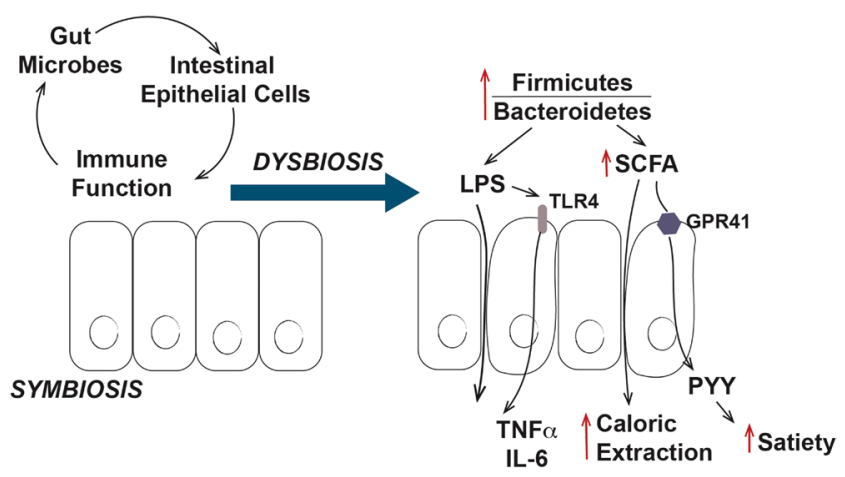

Figure 2 Schema showing symbiotic relationships between gut microbiome, immune system, and the intestinal epithelium. Obesity causes changes in the gut microbiota resulting in increased epithelial permeability, LPS leak and activation of TLR signaling in the gut, and increased caloric extraction and satiety due to increased production of SCFAs. GPR41 (G-protein receptor 41), IL-6 (interleukin 6), LPS (lipopolysaccharide), PYY (peptide tyrosine tyrosine), SCFA (shortchain fatty acid), TLR4 (toll-like receptor 4), TNF $\alpha$ (tumor necrosis factor alpha). 
Korem et al. 2015). In the context of obesity, the ratio of Firmicutes and Bacteroidetes, two phyla of bacteria that predominate in the gut, is increased (Ley et al. 2005, Turnbaugh et al. 2006, 2008, Riva et al. 2017). This change has been correlated to a state of gut dysbiosis which is characterized by tight junction protein loss and increased epithelial permeability (Kim et al. 2012, Saad et al. 2016).

One consequence of microbiota-induced gut dysbiosis is increased translocation of lipopolysaccharides (LPS) into the circulation resulting in low-level endotoxemia and induction of systemic inflammation (Fig. 2) (Cani et al. 2007, König et al. 2016, Bidne et al. 2018). Binding of LPS to the toll-like receptor 4 (TLR-4) in the intestinal epithelial also produces cytokines including TNF $\alpha$ and IL-6 which also contributes to systemic inflammation and metabolic alterations (Ding et al. 2010, Kim et al. 2012, Cox \& Blaser 2013, Everard et al. 2014). In addition to LPS, obesity-dependent gut dysbiosis results in increased dietary caloric extraction due to increased production and absorption of short-chain fatty acids (SCFAs) (Turnbaugh et al. 2006, Cox \& Blaser 2013, Saad et al. 2016). Importantly, SCFAs also regulate intestinal epithelial tight junctions, epithelial permeability and gut dysbiosis. Circulating SCFAs increase lipid storage in adipose tissue and cholesterol synthesis in the liver. However, they also increase the production of the satiety hormone PYY and have anti-inflammatory function (Cox \& Blaser 2013, Saad et al. 2016). Therefore, it is unclear how gut microbiota changes in SCFAs contributes to obesity. Together, these data have established the now well-accepted paradigm that obesity is a chronic condition characterized by low-grade inflammation, oxidative stress and increased gut permeability (Fig. 1).

\section{Physiological cytokine and chemokine signaling in the ovary}

Cytokines and chemokines play essential roles in follicular growth and ovulation during a normal estrous cycle. They arise from resident and infiltrating leukocytes that are localized in and recruited to the ovary, respectively. Specifically, Wu et al. localized activated T-lymphocytes, macrophages and monocytes and neutrophils in the theca layer during the follicular phase (Wu et al. 2006). After the ovulatory LH surge, dendritic cells are detected in the theca cells, while the numbers of neutrophils and macrophages in the theca cell layer are significantly increased indicating a role of these leukocytes during ovulation (Brännström et al. 1995, Cohen-Fredarow et al. 2014, Akison et al. 2018). Likewise, T-lymphocytes, granulocytes, monocytes, macrophages and dendritic cells are found in follicular fluid-derived cells of the pre-ovulatory follicle (Storeng et al. 2007).
The leukocytes described above as well as granulosa and theca cells secrete chemokines that recruit additional leukocytes to the ovary. Furthermore, a myriad of cytokines is produced which regulate somatic cell function during follicular growth and ovulation. For example, granulocyte-macrophage-colony stimulating factor (GM-CSF), monocyte chemoattractant protein 1 (MCP-1) and IL-8 proteins induce migration of macrophages into the ovary (Połeć et al. 2011, Field et al. 2014). Likewise, chemokine ligand 20 (CCL20) produced by the theca and granulosa cells stimulate an influx of macrophages (Al-Alem et al. 2015). Finally, RANTES (regulated upon activation of normal T-cell expressed and secreted) mediates influx of T-cells, eosinophils and mast cells into the ovary (Field et al. 2014). Cytokines regulate important functions in the ovary. For example, IL-6, interferon alpha (IFN $\alpha$ ) and IFN $\beta$ regulate cumulus expansion after the $\mathrm{LH}$ surge (Fan et al. 2009, Dam et al. 2015).

In addition to acting as chemokines, GM-CSF and IL-8, acting as cytokines, also regulate the ovarian cell functions. During follicular growth, GM-CSF increases preantral follicle progression and decreases granulosa cell proliferation and synthesis of $17 \beta$-estradiol (E2) and progesterone (P4) (Gilchrist et al. 2000, Wang et al. 2005, Zhang et al. 2008). Interleukin-8 stimulates follicular progression from preantral to pre-ovulatory stage (Goto et al. 1997). However, it inhibits E2 synthesis by granulosa cells and increases $\mathrm{P} 4$ synthesis by theca and granulosa cells (Shimizu et al. 2012, 2013). These studies suggest initiation of luteinization by GM-CSF and IL-8 during the ovulatory process. Additional studies demonstrate that IL-1 induces ovulation (Brännström \& Enskog 2002).

\section{Pathological cytokine and chemokine signaling in the ovary}

It should be noted that the abnormalities in ovarian function have been correlated with increased infiltration of the ovary by macrophages (Skaznik-Wikiel et al. 2016), increased expression and signaling of pro-inflammatory cytokines (Nteeba et al. 2014, Xie et al. 2016), and increased incidence of ovarian fibrosis (de Araújo et al. 2018). Obesity-dependent subfertility and infertility is also associated with pathological inflammation and oxidative stress (Agarwal et al. 2005a,b). Recent studies show increased localization of innate immune cells, evidence of inflammatory signaling and oxidative stress in ovaries from obesity animal models as well as obese women. For example, TNF $\alpha$, IL-6 and IL-8 expression and activity of their associated inflammatory signaling pathways (e.g. NFkB) are increased in ovaries from obese women and mice (Nteeba et al. 2013, Ruebel et al. 2016, Xie et al. 2016). Interestingly, female 
TNF $\alpha$-knockout mice $\left(\mathrm{Tnfa}^{-/-}\right)$show increased frequency of estrous cycles, increased granulosa cell proliferation and reduced oocyte apoptosis resulting in increased number of pups born over a 12-month breeding period (Cui et al. 2011). Finally, there is evidence of obesitydependent oxidative stress in the ovary (Igosheva et al. 2010). Sources of cytokines include ovarian somatic cells and leukocytes within the ovary (Nteeba et al. 2014, Ruebel et al. 2016, 2017, Xie et al. 2016). There are also pro-inflammatory cytokines (IL-1, IL-6, TNF $\alpha$ ) and oxidative stress factors $\left(\mathrm{H}_{2} \mathrm{O}_{2}\right.$, oxLDL) in follicular fluid which in some cases are correlated to circulating cytokines (Bausenwein et al. 2010, Buyuk et al. 2017, Gonzalez et al. 2018). Interestingly, IL-6 and TNF $\alpha$ are positively correlated with lipid concentrations in follicular fluid of obese women. Therefore, obesitydependent systemic inflammation and lipotoxicity may be transmitted to the ovary via follicular fluid, although additional studies are required to verify this occurrence. While physiological expression of cytokines is required for optimal ovarian functions, these data suggest that increased or aberrant expression of pro-inflammatory cytokines above a threshold level or at inappropriate time points during the estrous cycle impairs ovarian function.

\section{Metabolic and ovarian phenotypes of PCOS}

Polycystic ovary syndrome (PCOS) is an androgen excess disorder that impacts $7-10 \%$ of reproductive age women. Women with PCOS are at increased risk for development of obesity and type 2 diabetes (Rodgers et al. 2019) resulting in phenotypes that overlap with obese women without PCOS. For example, in a rat model of PCOS, tumor necrosis factor alpha (TNF $\alpha$ ) and MDA, which is a metabolite of lipid peroxidation, are increased indicating chronic ovarian inflammation and oxidative stress (Furat Rencber et al. 2018). Interestingly, the level of cytokines and MDA are also higher in obese PCOS compared to obese non-PCOS women, although both have higher TNF $\alpha$ and MDA levels than lean PCOS and lean controls (Alshammari et al. 2017, Artimani et al. 2018). These data suggest that PCOS exacerbates obesity-dependent ovarian inflammation and oxidative stress (Ressler et al. 2015). Distinct metabolic differences between obesity and PCOS include hyperandrogenemia, that is, obese women without PCOS have circulating total testosterone concentrations similar to lean control women (Keskin Kurt et al. 2014, Alshammari et al. 2017, Usta et al. 2018). Other hormones increased in obese PCOS patients compared to obese women include insulin/glucose, LH and E2 (Keskin Kurt et al. 2014, Usta et al. 2018). While triglyceride concentrations are similar between PCOS and non-PCOS obese women, there are distinct differences in the types of phosphatidylcholine and lyso-phosphatidylcholine species between obese PCOS and obese non-PCOS women (Li et al. 2017). Based on these data, it is clear that obese women with
PCOS have similar inflammatory and oxidative stress phenotypes to obese women. It should also be noted that there are PCOS women who have a normal BMI (Alshammari et al. 2017, Li et al. 2017, Usta et al. 2018). Therefore, there are obese women without PCOS and lean women with PCOS.

\section{Obesity disrupts ovarian function}

Several studies using rodent models or human samples demonstrate that obesity negatively impacts ovarian function. For example, estrous cyclicity is irregular in rodents fed a high-fat diet, with longer periods of diestrus and shortened estrus periods (Nteeba et al. 2014, Bazzano et al. 2015, de Araújo et al. 2018). Follicle growth and development is also altered by obesity. There is depletion of the primordial follicle pool and concomitant increases in progression of follicles to the antral stage (Nteeba et al. 2014, Wang et al. 2014, Shaznik-Wikiel et al. 2016). There are also increased numbers of atretic follicles (Wang et al. 2014, Wu et al. 2015, de Araújo et al. 2018). These phenotypes have been replicated in an Ossabaw pig model of obesity. In this model, obese pigs have elongated estrous cycles and increased numbers of antral and atretic follicles compared to lean counterparts (Newell-Fugate et al. 2015). Together, these data suggest that obesitydependent decreases in the number of primordial follicles and increases in the number of antral and atretic follicles may deplete the ovarian reserve and contribute to subfertility (Wang et al. 2014).

Granulosa cell apoptosis, which initiates follicular atresia, is increased in ovaries from obese mice and rats (Wu et al. 2015). In follicles that do not become atretic, it is reasonable to expect that the reduced number of granulosa cells per follicle also decreases E2 synthesis and secretion, which would directly impact both estrous cyclicity and follicle growth. Indeed, the mRNA abundance of Cyp19a1, which encodes the P450 aromatase protein, is decreased in ovaries from obese female mice (Nteeba et al. 2014, de Araújo et al. 2018). Likewise, the ratio of E2 to P4 and mRNA abundance of the steroidogenic acute regulatory protein (Star) and P450 aromatase (Cyp19a1) are decreased in obese mice during estrus (Nteeba et al. 2014, Pohlmeier et al. 2014).

\section{Oocyte quality is reduced due to obesity}

Obesity-induced abnormalities in folliculogenesis and ovulation can be rescued by ovarian stimulation with exogenous gonadotropins in both mice and women (Pohlmeier et al. 2014, Committee and Society 2015, Xie et al. 2016). However, pregnancy rates remain low and miscarriage rates high indicating that oocyte quality is impaired (Kawwass et al. 2016). Under normal conditions, when the oocyte reaches the end of the growth phase, it acquires the ability to resume 
meiosis, which is stimulated by luteinizing hormone (LH) and results in an oocyte terminated at metaphase II (Schroeder et al. 1990, Conti \& Franciosi 2018). $\mathrm{LH}$ also stimulates maturation of the cytoplasmic contents of the oocyte including accumulation and re-distribution of mitochondria, accumulation of essential nutrients and selective storage and degradation of RNAs and proteins (Mao et al. 2014). Under optimal conditions, coordination of nuclear and cytoplasmic maturation produces a high-quality oocyte competent for fertilization, pre-implantation development and ultimately embryo/fetal viability.

Oocytes collected from diet-induced obese mice have poor quality based on reduced in vitro embryonic development (Colton et al. 2002, 2003, Minge et al. 2008, Pohlmeier et al. 2014, Hou et al. 2016). Furthermore, poor oocyte quality can have longlasting effects on fetal growth and neural development (Luzzo et al. 2012). Interestingly, the metabolic effects of obesity, due to consumption of a high-fat diet, are reversed when mice are returned to a control diet. However, meiotic and cytoplasmic measures of oocyte quality remain poor (Reynolds et al. 2015). Women who are obese and use artificial reproductive technology (e.g. in vitro fertilization) have reduced pregnancy rates compared to their lean counterparts (Kumbak et al. 2012, Moragianni et al. 2012). However, these poor rates can be rescued by the use of donor oocytes from lean individuals (Bellver et al. 2007, Levens \& Skarulis 2008). Based on recent data described below, reduced pregnancy rates are attributed, in part, to reduced oocyte quality and abnormalities in pre-implantation embryo development. Like the somatic cells of the ovary, obesity induces oxidative stress in the oocyte which negatively impacts both meiotic and cytoplasmic maturation of the oocyte (Table 1).

\section{Meiotic maturation}

Successful meiotic maturation requires resumption of meiosis and the faithful segregation of chromosomes. Resumption of meiosis is characterized by germinal vesicle breakdown, progression from prophase $I$ to metaphase II and extrusion of the first polar body. Abnormalities during the resumption or progression of meiosis result in aneuploidy. Streptozotocin treatment of mice, which destroys the insulin-secreting pancreatic $\beta$-islet cells (Lenzen 2008), causes meiotic abnormalities (Colton et al. 2002, 2003, Wang et al. 2009). For example, the percentage of oocytes that undergo germinal vesicle breakdown (GVBD) is reduced when they are collected from streptozotocin-induced diabetic mice (Colton et al. 2002, 2003, Ratchford et al. 2007). There are also abnormalities in both spindle structure and chromosome alignment (Wang et al. 2009, Ou et al. 2012). It is important to note that both type 1 and type 2 diabetes results in hyperglycemia. Interestingly, when non-human primates received excess dietary sugar, meiotic resumption was impaired suggesting that hyperglycemia is an important contributor to meiotic resumption defects (Chaffin et al. 2014).

Disruption of meiosis, resulting in aneuploidy, has also been assessed using diet-induced obesity mouse and rat models (Hou et al. 2016, Wang et al. 2018). Like the streptozotocin-treated mice, high-fat diet-fed mice exhibit decreases in both GVBD, polar body extrusion, abnormal spindle structure and chromosome alignment (Luzzo et al. 2012, Zhang et al. 2015, Hou et al. 2016, Wang et al. 2018). Recent studies show a causative effect between accumulation of ROS in the oocyte and meiotic maturation defects. Zhang et al. showed that microinjection of mitochondria-localized deacetylase sirtuin 3 (Sirt 3) mRNA into oocytes of high-fat fed mice decreased ROS levels and rescued meiotic defects (Zhang et al. 2015). Likewise, knockdown of Sirt2 results in spindle defects and chromosome misalignment (Zhang et al. 2014). Wang et al. demonstrated that loss of TP53-induced glycolysis and apoptosis regulator (Tigar) expression increases ROS and spindle disorganization (Wang et al. 2018). Alternatively, when Tigar is overexpressed in oocytes from high-fat-fed mice, there is a reduction in ROS and reduced structural meiotic abnormalities. These data indicate that obesitydependent oxidative stress plays an important role in aneuploidy and ultimately embryo loss.

Interestingly, there is a significant number of firsttrimester pregnancy losses in obese individuals that have a normal karyotype (Landres et al. 2010). This is in striking contrast to pregnancy loss in individuals with advanced maternal age which are overwhelmingly due

Table 1 Obesity effects on oocyte maturation.

\begin{tabular}{ll}
\hline Effects & References \\
\hline $\begin{array}{l}\text { Mitosis } \\
\text { Decreased GV breakdown and polar }\end{array}$ & Colton et al. (2002, 2003), Ratchford et al. (2007), Chaffin et al. (2014), Hou et al. (2016), Wang et al. (2018) \\
$\begin{array}{l}\text { body extrusion } \\
\text { Spindle structure and chromosome } \\
\text { alignment abnormalities }\end{array}$ & Wang et al. (2009), Luzzo et al. (2012), Ou et al. (2012), Zhang et al. (2015), Hou et al. (2016) \\
$\begin{array}{l}\text { Cytoplasm } \\
\text { Mitochondria }\end{array}$ & Igosheva et al. (2010), Luzzo et al. (2012), Ou et al. (2012) \\
$\begin{array}{l}\text { Endoplasmic reticulum } \\
\text { mRNA abundance }\end{array}$ & Wu et al. (2010, 2012, 2015), Yang et al. (2012), Sutton-McDowall et al. (2015), Guzel et al. (2017) \\
& Wood et al. (2007), Pohlmeier et al. (2014), Hou et al. (2016), Xie et al. (2016), Ruebel et al. (2017) \\
\hline
\end{tabular}


to aneuploidy (Nagaoka et al. 2012). Together, these data suggest that obesity-dependent early pregnancy loss is also due to alternative oocyte abnormalities, in particular, cytoplasmic maturation of the oocyte.

\section{Mitochondrial dysfunction}

Mitochondria play an essential role in both oocyte maturation and pre-implantation embryo development. Indeed, mitochondrial dysfunction leads to abnormalities in meiotic resumption, fertilization and development of the embryo to the blastocyst stage (Van Blerkom 2011, Babayev \& Seli 2015). Like somatic cells, mitochondria in the oocyte are the site of oxidative phosphorylation and production of ATP. Treatment of oocytes with an ionophore that inhibits oxidative phosphorylation, and presumably the production of ATP, results in spindle and chromosome alignment defects (Ge et al. 2012) indicating that the mitochondria is an important energy source for meiotic maturation. It is important to note that efficient oxidative phosphorylation requires a high mitochondrial membrane potential, which increases as the oocyte grows and matures (Van Blerkom \& Davis 2007). In addition to metabolic functions, the numbers of mitochondria increase during oocyte growth to approximately 160,000 (Mahrous et al. 2012). However, the increase in maternally derived mitochondria are only essential for pre-implantation development but not oocyte maturation (Ge et al. 2012).

In the context of obesity, mitochondrial membrane potential is altered. Igosheva et al. and Luzzo et al. showed increases in membrane potential in MII oocytes and zygotes using a diet-induced model of obesity (Igosheva et al. 2010, Luzzo et al. 2012). Alternatively, Wu et al. showed decreased membrane potential in MII oocytes using a genetic model of obesity (Wu et al. 2015). Interestingly, Ou et al. showed increased membrane potential in germinal vesicle stage oocytes and decreased membrane potential in MII oocytes in a hyperinsulinemia model (Ou et al. 2012). These studies suggest that the mode of obesity development differentially dictates the metabolic potential of oocyte mitochondria. Additional studies are required to discriminate how diet, satiety suppression and hyperglycemia regulate changes in the membrane potential of mitochondria. Despite these discrepancies, all the studies showed increased levels of ROS in oocytes. Furthermore, they all showed abnormalities in spindle structure and/or chromosome alignment consistent with ionophore inhibition of mitochondrial oxidative phosphorylation.

\section{Endoplasmic reticulum stress}

As indicated earlier, obesity-dependent oxidative stress is the result of increased production of $\mathrm{O}_{2}{ }^{-}$and $\mathrm{H}_{2} \mathrm{O}_{2}$ (Fig. 1). Increased ROS also induces endoplasmic reticulum (ER) stress. The consequence is activation of the unfolding protein response (UPR) which includes increased expression of ATF4, ATF6, GRP78 and PERK (Guzel et al. 2017). Indeed, oocytes from obese mice or treatment of mouse oocytes with follicular fluid from obese women increases ATF6, ATF4 and GRP78 (Wu et al. 2010, 2015, Yang et al. 2012). This ER stress has been correlated with reduced ovulation, fertilization and/ or pre-implantation development, which is indicative of reduced oocyte quality (Wu et al. 2010, 2012, SuttonMcDowall et al. 2015). To determine the causative effect of ER stress on the oocyte, cumulus-oocyte complexes (COCs) have been treated with thapsigargin, which induces ER stress. This treatment decreases cumulus cell expansion, which is a marker of oocyte quality, and results in poor pre-implantation development rates (Wu et al. 2012). Treatment of COCs with palmitic acid similarly induces ER stress, decreases cumulus expansion and reduces pre-implantation development (Wu et al. 2012, Sutton-McDowall et al. 2015). It should be noted that thapsigargin treatment decreases mitochondrial membrane potential suggesting crosstalk between ER- and mitochondrial-dependent ROS production (Wu et al. 2012). Therefore, to definitively demonstrate that ER stress impairs oocyte quality, COCs treated with thapsigargin or palmitic acid or collected from obese mice were cultured in the presence of the ER stress inhibitor salubrinal (Wu et al. 2012, SuttonMcDowall et al. 2015). This treatment reverses the ER stress-induced phenotypes and suggest a direct role for ER stress-dependent decreases in oocyte quality.

\section{Regulation of oocyte mRNAs}

Under optimal conditions, approximately $0.5 \mathrm{ng}$ of total RNA are synthesized in growing oocytes due to a high rate of transcription which correlates with diffuse chromatin distribution (Gandolfi \& Gandolfi 2001). As the oocyte reaches its full-grown size, its chromatin compacts and surrounds the nucleolus (SN) at which time transcription rates dramatically decrease (Bouniol-Baly 1999). Posttranscriptional regulation of $\mathrm{mRNA}$ storage, translation and degradation becomes the predominate mechanism to regulate transcript abundance after the ovulatory surge of LH (Li et al. 2013, Svoboda et al. 2015). Selective degradation of mRNAs, which are initiated by the $\mathrm{LH}$ surge, continues after fertilization and are essential for activation of transcription from the embryonic genome. Importantly, a group of mRNAs called maternal effect genes remain relatively stable until later in development (one- to two-cell stages) and are essential for preimplantation development (Alizadeh et al. 2005, Su et al. 2007, Svoboda et al. 2015).

Microarray analysis and RNA sequencing of MII oocytes from obese women with or without PCOS demonstrated differences in gene expression profiles (Wood et al. 2007, Ruebel et al. 2017). Transcripts from these analyses fell into cytokine activity, transcription 
of DNA, regulation of mRNA storage and degradation, cell cycle regulators and maternal effect gene networks. Using a candidate gene approach, maternal effect genes were also increased in ovulated oocytes from diet-induced and satiety-suppressed mouse models of obesity (Pohlmeier et al. 2014). Similarly, the mRNA abundances of Dppa3, Pou5f1 and basonuclin 1 (Bnc1), which are maternal effect genes, were increased in ovaries from diet-induced obese mice collected immediately after ovulation (Xie et al. 2016). In this same model, the STAT3 transcription factor, which is activated by inflammatory signaling, binds to the promoter of Dppa3 suggesting that obesity-dependent inflammation regulates transcription of oocyte genes. Importantly, DPPA3 binds to di-methylated histone $\mathrm{H} 3$ on lysine 9 (H3K9me2), protecting 5-methycytosine to 5-hydroxymethylcytosine (Nakamura et al. 2007, 2012, Nakatani et al. 2015). Han et al. showed that oocytes isolated from high-fat fed mice had decreased DPPA3 protein, which altered DNA methylation (Han et al. 2018). Specifically, DNA methylation in the pronuclei of the zygote was altered. These data suggest that DPPA3 influences the epigenetic profile of the embryo that could have long-lasting effects on fetal development. In a preliminary experiment, Timme and Wood (unpublished data) showed that $\mathrm{H}_{2} \mathrm{O}_{2}$ induction of oxidative stress during oocyte maturation increases Pou5f1 mRNA abundance in not only MII oocytes but also two-cell embryos (Fig. 3). Loss of maternal effect gene expression terminates pre-implantation embryonic development (Hirasawa et al. 2008). However, it is unclear how increases in maternal effect gene expression impacts embryo development and therefore represents an area that requires additional studies. Interestingly high-fat-fed mice have decreased $\mathrm{H} 3 \mathrm{~K} 9$-me2 in germinal vesicle stage oocytes which is correlated with oxidative stress (Hou et al. 2016). This suggests that gene expression during oocyte growth is altered and may have impacted the number of mRNAs in a MII-stage oocyte.

\section{Potential role of the gut microbiome on female fertility}

Interestingly, bariatric surgery of obese women normalizes ovulatory patterns, improves conception rates, reduces pregnancy complications and improves fetal health (Guelinckx et al. 2009, Gosman et al. 2010). Bariatric surgery also improves metabolic function, which is attributed in part, to changes in the composition of the gut microbiome (Murphy et al. 2017, Shao et al. 2017). These data suggest that changes to the gut microbiome may impact fertility. Toward this end, studies in Drosophila melanogaster were performed and showed that loss of gut microbes suppressed oogenesis (Elgart et al. 2016). Studies from China, Spain and
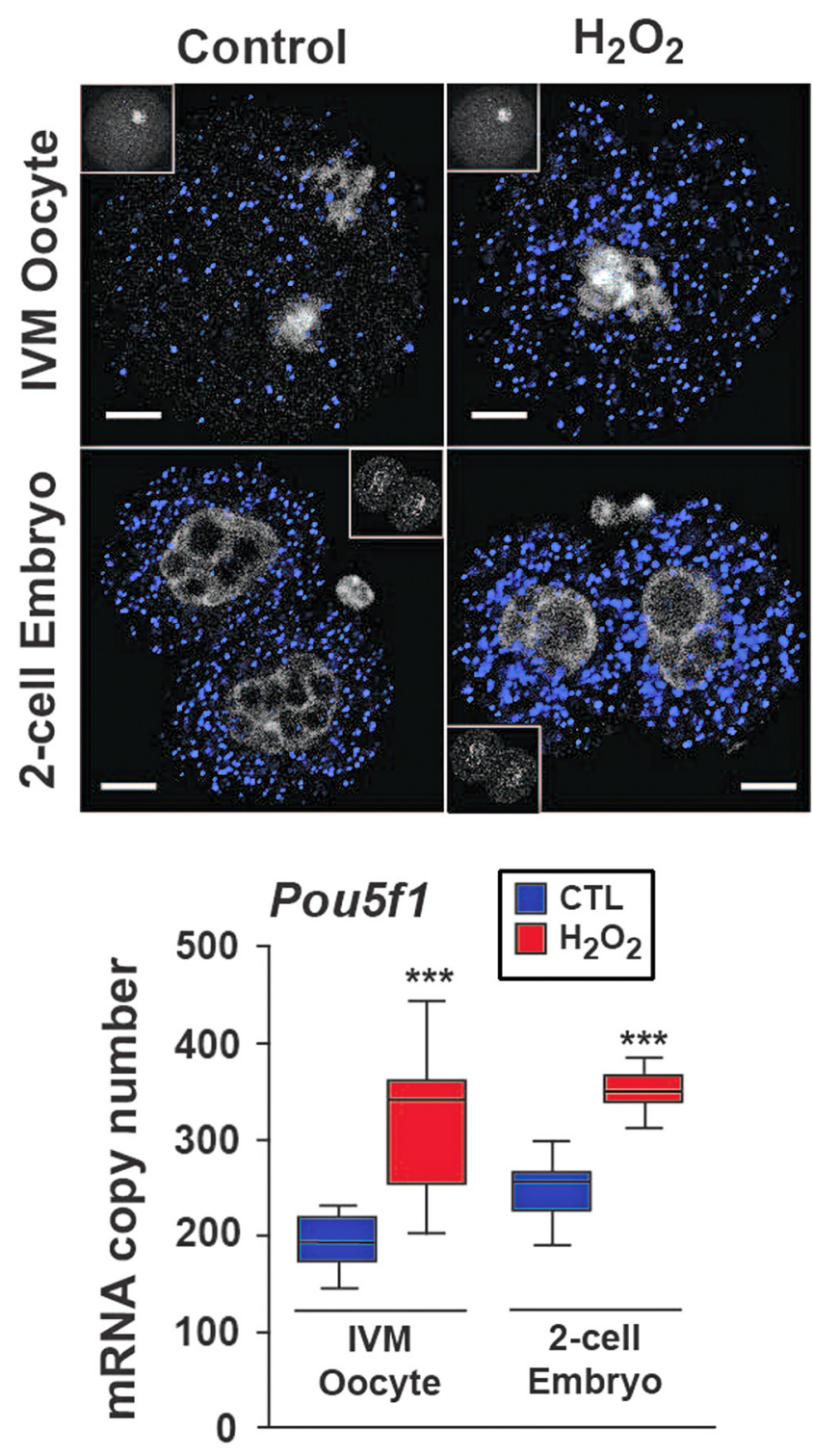

Figure 3 Oxidative stress increases the abundance of Pou5f1 in the MII oocyte and two-cell embryo. Oxidative stress was induced by $\mathrm{H}_{2} \mathrm{O}_{2}$ during in vitro maturation of the oocyte. Single molecule fluorescence in situ hybridization coupled with the Spot Finding and Tracking program determined the number of mRNAs in each oocyte and embryo. The copy number of mRNAs is indicated in the graph. Significance was determined using ANOVA. $P<0.001$ are indicated by ***.

Austria demonstrated association of PCOS with reduced diversity of the gut microbiome (Guo et al. 2016, Lindheim et al. 2017, Liu et al. 2017, Insenser et al. 2018). Furthermore, reduced diversity was most severe in obese women with PCOS. Using a mouse model of obesity, Xie et al. showed positive correlations between increases in the bacterial family Lachnospiracae and increased ovarian Tnfa expression (Xie et al. 2016). Importantly, Lachnospiracae was increased in high-fatfed C57BL/6J mice. 


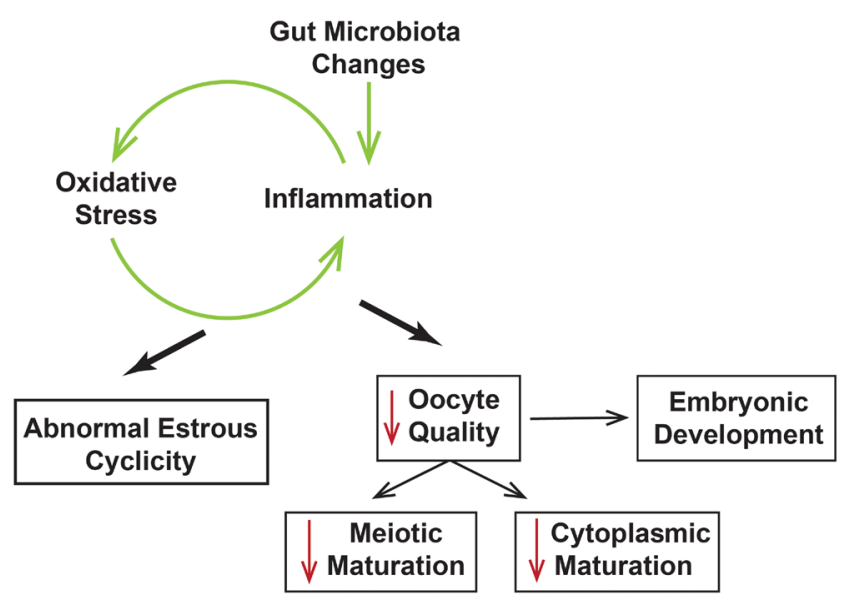

Figure 4 Model showing how changes in the gut microbiota, inflammation and oxidative stress affect ovarian estrous cyclicity and oocyte quality.

As described earlier, one consequence of gut microbiome changes is increased gut permeability due to loss of tight junctions resulting in leak of LPS and endotoxemia (Cani et al. 2007, 2012, König et al. 2016, Bidne et al. 2018). Interestingly, LPS is increased in the follicular fluid of cystic follicles (Shimizu et al. 2018). When bovine granulosa cells are treated in vitro with LPS, there is increased expression of IL-6, IL-8 and IL-1 $\beta$, which is a result of increased activation of TLR4 signal transduction (Sheldon \& Bromfield 2011, Price et al. 2013). These cytokines decrease expression of P450 aromatase (CYP19A1), which regulates synthesis and secretion of E2 by the bovine granulosa cells (Price et al. 2013, Magata et al. 2014, Shimizu et al. 2018). Furthermore, LPS disrupts meiotic resumption and spindle structure, mitochondrial membrane potential and decreases blastocysts rates and the ratio of trophectoderm and inner cell mass cell numbers (Sheldon \& Bromfield 2011, Magata \& Shimizu 2017).

Together, these studies suggest that changes in the gut microbiome, which increase LPS concentration, impact both ovarian steroidogenesis and oocyte quality. However, studies showing a causative effect of changes in the gut microbiome on obesity-dependent changes in the ovary are required.

\section{Conclusions}

In the last decade, the negative impact of obesity on ovarian function and oocyte quality has become evident. It is specifically tied to increases in inflammation and oxidative stress and potentially obesity-dependent changes in the gut microbiome (Fig. 4). However, future studies are required to delineate the mechanisms by which inflammation, oxidative stress and gut microbiome changes affect the ovary and oocyte. The impetus of these studies is to identify targets that can be used to therapeutically improve fertility in women who are obese or have metabolic dysfunction.

\section{Declaration of interest}

The authors declare that there is no conflict of interest that could be perceived as prejudicing the impartiality of this review.

\section{Funding}

This work was supported by the Nebraska Agricultural Experiment Station with funding from the Hatch Multistate Research capacity funding program (Accession Numbers 232435 and 1013511) from the USDA National Institute of Food and Agriculture.

\section{References}

Agarwal A, Gupta S \& Sharma R 2005a Oxidative stress and its implications in female infertility - a clinician's perspective. Reproductive Biomedicine Online 11 641-650. (https://doi.org/10.1016/S1472-6483(10)61174-1)

Agarwal A, Gupta S \& Sharma RK 2005b Role of oxidative stress in female reproduction. Reproductive Biology and Endocrinology 3 28. (https:// doi.org/10.1186/1477-7827-3-28)

Akison LK, Robertson SA, Gonzalez MB, Richards JS, Smith CW, Russell DL \& Robker RL 2018 Regulation of the ovarian inflammatory response at ovulation by nuclear progesterone receptor. American Journal of Reproductive Immunology 79 e12835. (https://doi.org/10.1111/ aji.12835)

Al-Alem L, Puttabyatappa M, Rosewell K, Brännström M, Akin J, Boldt J, Muse K \& Curry TE 2015 Chemokine ligand 20: a signal for leukocyte recruitment during human ovulation? Endocrinology 156 3358-3369. (https://doi.org/10.1210/en.2014-1874)

Alizadeh Z, Kageyama SI \& Aoki F 2005 Degradation of maternal mRNA in mouse embryos: selective degradation of specific mRNAs after fertilization. Molecular Reproduction and Development 72 281-290. (https://doi.org/10.1002/mrd.20340)

Alshammari G, Khan R, Brameld J, Amer S \& Lomax MA 2017 Gene expression of inflammatory markers in adipose tissue between obese women with polycystic ovary and normal obese women. European Review for Medical and Pharmacological Sciences 21 1099-1105.

Artimani T, Karimi J, Mehdizadeh M, Yavangi M, Khanlarzadeh E, Ghorbani M, Asadi S \& Kheiripour N 2018 Evaluation of pro-oxidantantioxidant balance (PAB) and its association with inflammatory cytokines in polycystic ovary syndrome (PCOS). Gynecological Endocrinology 34 148-152. (https://doi.org/10.1080/09513590.2017.1371691)

Babayev E \& Seli E 2015 Oocyte mitochondrial function and reproduction. Current Opinion in Obstetrics and Gynecology 27 175-181. (https://doi. org/10.1097/GCO.0000000000000164)

Bausenwein J, Serke H, Eberle K, Hirrlinger J, Jogschies P, Hmeidan FA, Blumenauer V \& Spanel-Borowski K 2010 Elevated levels of oxidized low-density lipoprotein and of catalase activity in follicular fluid of obese women. Molecular Human Reproduction 16 117-124. (https;// doi.org/10.1093/molehr/gap078)

Bazzano MV, Torelli C, Pustovrh MC, Paz DA \& Elia EM 2015 Obesity induced by cafeteria diet disrupts fertility in the rat by affecting multiple ovarian targets. Reproductive Biomedicine Online 31 655-667. (https:// doi.org/10.1016/j.rbmo.2015.08.004)

Bedard K \& Krause KH 2007 The NOX family of ROS-generating NADPH oxidases: physiology and pathophysiology. Physiological Reviews 87 245-313. (https://doi.org/10.1152/physrev.00044.2005)

Belizário JE \& Napolitano M 2015 Human microbiomes and their roles in dysbiosis, common diseases, and novel therapeutic approaches. Frontiers in Microbiology 6 1050. (https://doi.org/10.3389/fmicb.2015.01050)

Bellver J, Melo MAB, Bosch E, Serra V, Remohí J \& Pellicer A 2007 Obesity and poor reproductive outcome: the potential role of the endometrium. 
Fertility and Sterility $\mathbf{8 8} 446-451 . \quad$ (https://doi.org/10.1016/j. fertnstert.2006.11.162)

Bidne KL, Dickson MJ, Ross JW, Baumgard LH \& Keating AF 2018 Disruption of female reproductive function by endotoxins. Reproduction 155 R169-R181. (https://doi.org/10.1530/REP-17-0406)

Biswas SK 2016 Does the interdependence between oxidative stress and inflammation explain the antioxidant paradox? Oxidative Medicine and Cellular Longevity 2016 5698931. (https://doi. org/10.1155/2016/5698931)

Bouniol-Baly C, Hamraoui L, Guibert J, Beaujean N, Szöllösi MS \& Debey P 1999 Differential transcriptional activity associated with chromatin configuration in fully grown mouse germinal vesicle oocytes. Biology of Reproduction 60 580-587. (https://doi.org/10.1095/biolreprod60.3.580)

Brännström M \& Enskog A 2002 Leukocyte networks and ovulation. Journal of Reproductive Immunology 57 47-60. (https://doi.org/10.1016/S01650378(02)00009-8)

Brännström M, Bonello N, Norman RJ \& Robertson SA 1995 Reduction of ovulation rate in the rat by administration of a neutrophil-depleting monoclonal antibody. Journal of Reproductive Immunology 29 265-270. (https://doi.org/10.1016/0165-0378(95)00941-D)

Bromfield JJ \& Sheldon IM 2011 Lipopolysaccharide initiates inflammation in bovine granulosa cells via the TLR4 pathway and perturbs oocyte meiotic progression in vitro. Endocrinology 152 5029-5040. (https://doi. org/10.1210/en.2011-1124)

Broughton DE \& Moley KH 2017 Obesity and female infertility: potential mediators of obesity's impact. Fertility and Sterility 107 840-847. (https:// doi.org/10.1016/j.fertnstert.2017.01.017)

Brown GC \& Borutaite V 2012 There is no evidence that mitochondria are the main source of reactive oxygen species in mammalian cells. Mitochondrion 12 1-4. (https://doi.org/10.1016/j.mito.2011.02.001)

Buccione R, Schroeder AC \& Eppig JJ 1990 Interactions between somatic cells and germ cells throughout mammalian oogenesis. Biology of Reproduction 43 543-547. (https://doi.org/10.1095/biolreprod43.4.543)

Buyuk E, Asemota OA, Merhi Z, Charron MJ, Berger DS, Zapantis A \& Jindal SK 2017 Serum and follicular fluid monocyte chemotactic protein-1 levels are elevated in obese women and are associated with poorer clinical pregnancy rate after in vitro fertilization: a pilot study. Fertility and Sterility 107 632-640 e633. (https://doi.org/10.1016/j. fertnstert.2016.12.023)

Camp JG, Kanther M, Semova I \& Rawls JF 2009 Patterns and scales in gastrointestinal microbial ecology. Gastroenterology 136 1989-2002. (https://doi.org/10.1053/j.gastro.2009.02.075)

Cani PD, Amar J, Iglesias MA, Poggi M, Knauf C, Bastelica D, Neyrinck AM, Fava F, Tuohy KM, Chabo C et al. 2007 Metabolic endotoxemia initiates obesity and insulin resistance. Diabetes 56 1761-1772.

Cani PD, Osto M, Geurts L \& Everard A 2012 Involvement of gut microbiota in the development of low-grade inflammation and type 2 diabetes associated with obesity. Gut Microbes 3 279-288. (https://doi. org/10.4161/gmic.19625)

Chaffin CL, Latham KE, Mtango NR, Midic U \& VandeVoort CA 2014 Dietary sugar in healthy female primates perturbs oocyte maturation and in vitro preimplantation embryo development. Endocrinology 155 2688-2695. (https://doi.org/10.1210/en.2014-1104)

Cho I \& Blaser MJ 2012 The human microbiome: at the interface of health and disease. Nature Reviews: Genetics 13 260-270. (https://doi. org/10.1038/nrg3182)

Chong WC, Shastri MD \& Eri R 2017 Endoplasmic reticulum stress and oxidative stress: a vicious nexus implicated in bowel disease pathophysiology. International Journal of Molecular Sciences 18771. (https://doi.org/10.3390/ijms18040771)

Cohen-Fredarow A, Tadmor A, Raz T, Meterani N, Addadi Y, Nevo N, Solomonov I, Sagi I, Mor G, Neeman M et al. 2014 Ovarian dendritic cells act as a double-edged pro-ovulatory and anti-inflammatory sword. Molecular Endocrinology 28 1039-1054. (https://doi.org/10.1210/ me.2013-1400)

Colton SA, Pieper GM \& Downs SM 2002 Altered meiotic regulation in oocytes from diabetic mice. Biology of Reproduction 67 220-231. (https://doi.org/10.1095/biolreprod67.1.220)

Colton SA, Humpherson PG, Leese HJ \& Downs SM 2003 Physiological changes in oocyte-cumulus cell complexes from diabetic mice that potentially influence meiotic Regulation1. Biology of Reproduction 69 761-770. (https://doi.org/10.1095/biolreprod.102.013649)
Conti M \& Franciosi F 2018 Acquisition of oocyte competence to develop as an embryo: integrated nuclear and cytoplasmic events. Human Reproduction Update 24 245-266. (https://doi.org/10.1093/humupd/ dmx040)

Cox LM \& Blaser MJ 2013 Pathways in microbe-induced obesity. Cell Metabolism 17 883-894. (https://doi.org/10.1016/j.cmet.2013.05.004)

Cui LL, Yang G, Pan J \& Zhang C 2011 Tumor necrosis factor alpha knockout increases fertility of mice. Theriogenology 75 867-876. (https://doi. org/10.1016/j.theriogenology.2010.10.029)

Dam PTM, Jang Y-J, Chun S-Y, Park J-I, Moon W-J \& Cho M-K 2015 Cumulus cell-expressed type I interferons induce cumulus expansion in mice. Biology of Reproduction 9220.

de Araújo JFP, Podratz PL, Sena GC, Merlo E, Freitas-Lima LC, Ayub JGM, Pereira AFZ, Santos-Silva AP, Miranda-Alves L, Silva IV et al. 2018 The obesogen tributyltin induces abnormal ovarian adipogenesis in adult female rats. Toxicology Letters 295 99-114. (https://doi.org/10.1016/j. toxlet.2018.06.1068)

Ding S, Chi MM, Scull BP, Rigby R, Schwerbrock NMJ, Magness S, Jobin C \& Lund PK 2010 High-fat diet: bacteria interactions promote intestinal inflammation which precedes and correlates with obesity and insulin resistance in mouse. PLoS ONE 5 e12191. (https://doi.org/10.1371/ journal.pone.0012191)

Elgart M, Stern S, Salton O, Gnainsky Y, Heifetz Y \& Soen Y 2016 Impact of gut microbiota on the fly's germ line. Nature Communications 7 11280. (https://doi.org/10.1038/ncomms11280)

Engin A 2017 Fat cell and fatty acid turnover in obesity. In Obesity and Lipotoxicity, pp 135-160. Eds AB Engin \& A Engin. Cham: Springer International Publishing.

Ertunc ME \& Hotamisligil GS 2016 Lipid signaling and lipotoxicity in metaflammation: indications for metabolic disease pathogenesis and treatment. Journal of Lipid Research 57 2099-2114. (https://doi. org/10.1194/jlr.R066514)

Everard A, Geurts L, Caesar R, Van Hul M, Matamoros S, Duparc T, Denis RGP, Cochez P, Pierard F, Castel J et al. 2014 Intestinal epithelial MyD88 is a sensor switching host metabolism towards obesity according to nutritional status. Nature Communications 5 5648. (https://doi. org/10.1038/ncomms6648)

Fedorcsák P, Ráki M \& Storeng R 2007 Characterization and depletion of leukocytes from cells isolated from the pre-ovulatory ovarian follicle. Human Reproduction 22 989-994. (https://doi.org/10.1093/humrep/ del491)

Field SL, Dasgupta T, Cummings M \& Orsi NM 2014 Cytokines in ovarian folliculogenesis, oocyte maturation and luteinisation. Molecular Reproduction and Development 81 284-314. (https://doi.org/10.1002/ mrd.22285)

Finkelstein EA, Khavjou OA, Thompson H, Trogdon JG, Pan L, Sherry B \& Dietz W 2012 Obesity and severe obesity forecasts through 2030. American Journal of Preventive Medicine 42 563-570. (https://doi. org/10.1016/j.amepre.2011.10.026)

Furat Rencber S, Kurnaz Ozbek S, Eraldemır C, Sezer Z, Kum T, Ceylan S \& Guzel E 2018 Effect of resveratrol and metformin on ovarian reserve and ultrastructure in PCOS: an experimental study. Journal of Ovarian Research 11 55. (https://doi.org/10.1186/s13048-018-0427-7)

Gandolfi TALB \& Gandolfi F 2001 The maternal legacy to the embryo: cytoplasmic components and their effects on early development. Theriogenology 55 1255-1276. (https://doi.org/10.1016/S0093691X(01)00481-2)

Garn H, Bahn S, Baune BT, Binder EB, Bisgaard H, Chatila TA, Chavakis T, Culmsee C, Dannlowski U, Gay S et al. 2016 Current concepts in chronic inflammatory diseases: interactions between microbes, cellular metabolism, and inflammation. Journal of Allergy and Clinical Immunology 138 47-56. (https://doi.org/10.1016/j.jaci.2016.02.046)

Ge H, Tollner TL, Hu Z, Dai M, Li X, Guan H, Shan D, Zhang X, Lv J, Huang C et al. 2012 The importance of mitochondrial metabolic activity and mitochondrial DNA replication during oocyte maturation in vitro on oocyte quality and subsequent embryo developmental competence. Molecular Reproduction and Development 79 392-401. (https://doi. org/10.1002/mrd.22042)

Gilchrist RB, Rowe DB, Ritter LJ, Robertson SA, Norman RJ \& Armstrong DT 2000 Effect of granulocyte-macrophage colony-stimulating factor deficiency on ovarian follicular cell function. Journal of Reproduction and Fertility 120 283-292. (https://doi.org/10.1530/jrf.0.1200283) 
Gonzalez MB, Lane M, Knight EJ \& Robker RL 2018 Inflammatory markers in human follicular fluid correlate with lipid levels and Body Mass Index. Journal of Reproductive Immunology 130 25-29. (https://doi. org/10.1016/j.jri.2018.08.005)

Gosman GG, King WC, Schrope B, Steffen KJ, Strain GW, Courcoulas AP, Flum DR, Pender JR \& Simhan HN 2010 Reproductive health of women electing bariatric surgery. Fertility and Sterility 94 1426-1431. (https:// doi.org/10.1016/j.fertnstert.2009.08.028)

Goto J, Kanayama N, Asahina T, Okada Y, Kobayashi T \& Terao T 1997 Induction of follicular growth by exogenous interleukin-8. Human Reproduction 12 2729-2734. (https://doi.org/10.1093/ humrep/12.12.2729)

Guelinckx I, Devlieger R \& Vansant G 2009 Reproductive outcome after bariatric surgery: a critical review. Human Reproduction Update 15 189-201. (https://doi.org/10.1093/humupd/dmn057)

Guo Y, Qi Y, Yang X, Zhao L, Wen S, Liu Y \& Tang L 2016 Association between polycystic ovary syndrome and gut microbiota. PLOS ONE 11 e0153196. (https://doi.org/10.1371/journal.pone.0153196)

Guzel E, Arlier S, Guzeloglu-Kayisli O, Tabak MS, Ekiz T, Semerci N, Larsen K, Schatz F, Lockwood CJ \& Kayisli UA 2017 Endoplasmic reticulum stress and homeostasis in reproductive physiology and pathology. International Journal of Molecular Sciences 18 E792. (https:// doi.org/10.3390/ijms18040792)

Hales CM, Carroll MD, Fryar CD \& Ogden CL 2017 Prevalence of Obesity Among Adults and Youth: United States, 2015-2016. NCHS Data Brief, No. 288. Hyattsville, MD: National Center for Health Statistics.

Han L, Ren C, Li L, Li X, Ge J, Wang H, Miao YL, Guo X, Moley KH, Shu W et al. 2018 Embryonic defects induced by maternal obesity in mice derive from Stella insufficiency in oocytes. Nature Genetics $\mathbf{5 0}$ 432-442. (https://doi.org/10.1038/s41588-018-0055-6)

Hirasawa R, Chiba H, Kaneda M, Tajima S, Li E, Jaenisch R \& Sasaki H 2008 Maternal and zygotic Dnmt1 are necessary and sufficient for the maintenance of DNA methylation imprints during preimplantation development. Genes and Development 22 1607-1616. (https://doi. org/10.1101/gad.1667008)

Hou YJ, Zhu CC, Duan X, Liu HL, Wang Q \& Sun SC 2016 Both diet and gene mutation induced obesity affect oocyte quality in mice. Scientific Reports 6 18858. (https://doi.org/10.1038/srep18858)

Hussain T, Tan B, Yin Y, Blachier F, Tossou MCB \& Rahu N 2016 Oxidative stress and inflammation: what polyphenols can do for us? Oxidative Medicine and Cellular Longevity 2016 1-9. (https://doi. org/10.1155/2016/7432797)

Igosheva N, Abramov AY, Poston L, Eckert JJ, Fleming TP, Duchen MR \& McConnell J 2010 Maternal diet-induced obesity alters mitochondrial activity and redox status in mouse oocytes and zygotes. PLOS ONE 5 e10074. (https://doi.org/10.1371/journal.pone.0010074)

Insenser M, Murri M, Del Campo R, Martínez-García MÁ, FernándezDurán E \& Escobar-Morreale HF 2018 Gut microbiota and the polycystic ovary syndrome: influence of sex, sex hormones, and obesity. Journal of Clinical Endocrinology and Metabolism 103 2552-2562. (https://doi. org/10.1210/jc.2017-02799)

Kawwass JF, Kulkarni AD, Hipp HS, Crawford S, Kissin DM \& Jamieson DJ 2016 Extremities of body mass index and their association with pregnancy outcomes in women undergoing in vitro fertilization in the United States. Fertility and Sterility 106 1742-1750. (https://doi. org/10.1016/j.fertnstert.2016.08.028)

Keskin Kurt R, Okyay AG, Hakverdi AU, Gungoren A, Dolapcioglu KS, Karateke A \& Dogan MO 2014 The effect of obesity on inflammatory markers in patients with PCOS: a BMI-matched case - control study. Archives of Gynecology and Obstetrics 290 315-319. (https://doi. org/10.1007/s00404-014-3199-3)

Kim KA, Gu W, Lee IA, Joh EH \& Kim DH 2012 High fat diet-induced gut microbiota exacerbates inflammation and obesity in mice via the TLR4 signaling pathway. PLOS ONE 7 e47713. (https://doi.org/10.1371/ journal.pone.0047713)

Klenov VE \& Jungheim ES 2014 Obesity and reproductive function: a review of the evidence. Current Opinion in Obstetrics and Gynecology 26 455-460. (https://doi.org/10.1097/GCO.0000000000000113)

König J, Wells J, Cani PD, García-Ródenas CL, MacDonald T, Mercenier A, Whyte J, Troost F \& Brummer RJ 2016 Human intestinal barrier function in health and disease. Clinical and Translational Gastroenterology 7 e196. (https://doi.org/10.1038/ctg.2016.54)
Korem T, Zeevi D, Suez, Weinberger A, Avnit-Sagi T, Pompan-Lotan M, Matot E, Jona G, Harmelin A, Cohen N et al. 2015 Growth dynamics of gut microbiota in health and disease inferred from single metagenomic samples. Science 349 1101-1106. (https://doi.org/10.1126/science. aac4812)

Kumbak B, Oral E \& Bukulmez O 2012 Female obesity and assisted reproductive technologies. Seminars in Reproductive Medicine 30 507-516. (https://doi.org/10.1055/s-0032-1328879)

Kuroda M \& Sakaue H 2017 Adipocyte death and chronic inflammation in obesity. Journal of Medical Investigation 64 193-196. (https://doi. org/10.2152/jmi.64.193)

Landres IV, Milki AA \& Lathi RB 2010 Karyotype of miscarriages in relation to maternal weight. Human Reproduction 25 1123-1126. (https://doi. org/10.1093/humrep/deq025)

Landskron G, De Fuente $M$, Thuwajit P, Thuwajit C \& Hermoso MA 2014 Review article inflammation and cytokines in the tumor microenvironment. Journal of Immunology Research 201414918.

Lenzen S 2008 The mechanisms of alloxan- and streptozotocin-induced diabetes. Diabetologia 51 216-226. (https://doi.org/10.1007/s00125007-0886-7)

Levens ED \& Skarulis MC 2008 Assessing the role of endometrial alteration among obese patients undergoing assisted reproduction. Fertility and Sterility 89 1606-1608. (https://doi.org/10.1016/j.fertnstert.2007.03.079)

Ley RE, Bäckhed F, Turnbaugh P, Lozupone CA, Knight RD \& Gordon J 2005 Obesity alters gut microbial ecology. PNAS 102 11070-11075. (https://doi.org/10.1073/pnas.0504978102)

Li L, Lu X \& Dean J 2013 The maternal to zygotic transition in mammals. Molecular Aspects of Medicine 34 919-938. (https://doi.org/10.1016/j. mam.2013.01.003)

Li S, Chu Q, Ma J, Sun Y, Tao T, Huang R, Liao Y, Yue J, Zheng J, Wang L et al. 2017 Discovery of novel lipid profiles in PCOS: do insulin and androgen oppositely regulate bioactive lipid production? Journal of Clinical Endocrinology and Metabolism 102 810-821. (https://doi. org/10.1210/jc.2016-2692)

Lindheim L, Bashir M, Münzker J, Trummer C, Zachhuber V, Leber B, Horvath A, Pieber TR, Gorkiewicz G, Stadlbauer V et al. 2017 Alterations in gut microbiome composition and barrier function are associated with reproductive and metabolic defects in women with polycystic ovary syndrome (PCOS): a pilot study. PLOS ONE 12 e0168390. (https://doi. org/10.1371/journal.pone.0168390)

Liu Z, de Matos DG, Fan HY, Shimada M, Palmer S \& Richards JS 2009 Interleukin-6: an autocrine regulator of the mouse cumulus cell-oocyte complex expansion process. Endocrinology 150 3360-3368. (https:// doi.org/10.1210/en.2008-1532)

Liu R, Zhang C, Shi Y, Zhang F, Li L, Wang X, Ling Y, Fu H, Dong W, Shen J et al. 2017 Dysbiosis of gut microbiota associated with clinical parameters in polycystic ovary syndrome. Frontiers in Microbiology $\mathbf{8}$ 324. (https://doi.org/10.3389/fmicb.2017.00324)

Lu X, Murphy TC, Nanes MS \& Hart CM 2010 PPAR $\gamma$ regulates hypoxiainduced Nox4 expression in human pulmonary artery smooth muscle cells through NF-kB. American Journal of Physiology: Lung Cellular and Molecular Physiology 299 L559-L566. (https://doi.org/10.1152/ ajplung.00090.2010)

Luzzo KM, Wang Q, Purcell SH, Chi M, Jimenez PT, Grindler N, Schedl T \& Moley KH 2012 High fat diet induced developmental defects in the mouse: oocyte meiotic aneuploidy and fetal growth retardation/ brain defects. PLOS ONE 7 e49217. (https://doi.org/10.1371/journal. pone.0049217)

Magata F \& Shimizu T 2017 Effect of lipopolysaccharide on developmental competence of oocytes. Reproductive Toxicology 71 1-7. (https://doi. org/10.1016/j.reprotox.2017.04.001)

Magata F, Horiuchi M, Echizenya R, Miura R, Chiba S, Matsui M, Miyamoto A, Kobayashi Y \& Shimizu T 2014 Lipopolysaccharide in ovarian follicular fluid influences the steroid production in large follicles of dairy cows. Animal Reproduction Science 144 6-13. (https://doi. org/10.1016/j.anireprosci.2013.11.005)

Mahrous E, Yang Q \& Clarke HJ 2012 Regulation of mitochondrial DNA accumulation during oocyte growth and meiotic maturation in the mouse. Reproduction 144 177-185. (https://doi.org/10.1530/REP-12-0113)

Mailloux RJ 2018 Mitochondrial antioxidants and the maintenance of cellular hydrogen peroxide levels. Oxidative Medicine and Cellular Longevity 2018 7857251. (https://doi.org/10.1155/2018/7857251) 
Mao L, Lou H, Lou Y, Wang N \& Jin F 2014 Behaviour of cytoplasmic organelles and cytoskeleton during oocyte maturation. Reproductive Biomedicine Online $28 \quad 284-299 . \quad$ (https://doi.org/10.1016/j. rbmo.2013.10.016)

Minge CE, Bennett BD, Norman RJ \& Robker RL 2008 Peroxisome proliferator-activated receptor- $\gamma$ agonist rosiglitazone reverses the adverse effects of diet-induced obesity on oocyte quality. Endocrinology 149 2646-2656. (https://doi.org/10.1210/en.2007-1570)

Moragianni VA, Jones SML \& Ryley DA 2012 The effect of body mass index on the outcomes of first assisted reproductive technology cycles. Fertility and Sterility 98 102-108. (https://doi.org/10.1016/j. fertnstert.2012.04.004

Murphy R, Tsai P, Jüllig M, Liu A, Plank L \& Booth M 2017 Differential changes in gut microbiota after gastric bypass and sleeve gastrectomy bariatric surgery vary according to diabetes remission. Obesity Surgery 27 917-925. (https://doi.org/10.1007/s11695-016-2399-2)

Nagaoka SI, Hassold TJ \& Hunt PA 2012 Human aneuploidy: mechanisms and new insights into an age-old problem. Nature Reviews: Genetics 13 493-504. (https://doi.org/10.1038/nrg3245)

Nakamura T, Arai Y, Umehara H, Masuhara M, Kimura T, Taniguchi H, Sekimoto T, Ikawa M, Yoneda Y, Okabe M et al. 2007 PGC7/Stella protects against DNA demethylation in early embryogenesis. Nature Cell Biology 9 64-71. (https://doi.org/10.1038/ncb1519)

Nakamura T, Liu YJ, Nakashima H, Umehara H, Inoue K, Matoba S, Tachibana M, Ogura A, Shinkai Y \& Nakano T 2012 PGC7 binds histone $\mathrm{H} 3 \mathrm{~K} 9 \mathrm{me} 2$ to protect against conversion of $5 \mathrm{mC}$ to $5 \mathrm{hmC}$ in early embryos. Nature 486 415-419. (https://doi.org/10.1038/nature11093)

Nakatani T, Yamagata K, Kimura T, Oda M, Nakashima H, Hori M, Sekita Y, Arakawa T, Nakamura T \& Nakano T 2015 Stella preserves maternal chromosome integrity by inhibiting 5hmC-induced $\mathrm{H} 2 \mathrm{AX}$ accumulation. EMBO Reports 16 582-589. (https://doi.org/10.15252/ embr.201439427)

Newell-Fugate AE, Taibl JN, Alloosh M, Sturek M, Bahr JM, Nowak RA \& Krisher RL 2015 Effects of obesity and metabolic syndrome on steroidogenesis and folliculogenesis in female Ossabaw minipigs. PLoS One 10 e0128749. (https://doi.org/10.1371/journal.pone.0128749)

Nordgren M \& Fransen M 2014 Peroxisomal metabolism and oxidative stress. Biochimie 98 56-62. (https://doi.org/10.1016/j.biochi.2013.07.026

Nteeba J, Ortinau LC, Perfield JW \& Keating AF 2013 Diet-induced obesity alters immune cell infiltration and expression of inflammatory cytokine genes in mouse ovarian and peri-ovarian adipose depot tissues. Molecular Reproduction and Development 80 948-958. (https://doi. org/10.1002/mrd.22231)

Nteeba J, Ganesan S \& Keating AF 2014 Progressive obesity alters ovarian folliculogenesis with impacts on pro-inflammatory and steroidogenic signaling in female Mice1. Biology of Reproduction 91 1-11. (https:// doi.org/10.1095/biolreprod.114.121343)

Oliveira-Marques V, Marinho HS, Cyrne L \& Antunes F 2009 Role of hydrogen peroxide in NF- $\kappa \mathrm{B}$ activation: from inducer to modulator Antioxidants and Redox Signaling 11 2223-2243. (https://doi. org/10.1089/ars.2009.2601)

Ou XH, Li S, Wang ZB, Li M, Quan S, Xing F, Guo L, Chao SB, Chen Z, Liang XW et al. 2012 Maternal insulin resistance causes oxidative stress and mitochondrial dysfunction in mouse oocytes. Human Reproduction 27 2130-2145. (https://doi.org/10.1093/humrep/des137)

Ouchi N, Parker JL, Lugus JJ \& Walsh K 2011 Adipokines in inflammation and metabolic disease. Nature Reviews: Immunology 11 85-97. (https:// doi.org/10.1038/nri2921)

Pandey S \& Bhattacharya S 2010 Impact of obesity on gynecology. Women's Health 6 107-117. (https://doi.org/10.2217/whe.09.77)

Penzias AS 2012 Recurrent IVF failure: other factors. Fertility and Sterility 97 1033-1038. (https://doi.org/10.1016/j.fertnstert.2012.03.017)

Piya MK, McTernan PG \& Kumar S 2013 Adipokine inflammation and insulin resistance: the role of glucose, lipids and endotoxin. Journal of Endocrinology 216 T1-T15. (https://doi.org/10.1530/JOE-12-0498)

Pohlmeier WE, Xie F, Kurz SG, Lu N \& Wood JR 2014 Progressive obesity alters the steroidogenic response to ovulatory stimulation and increases the abundance of mRNAs stored in the ovulated oocyte. Molecular Reproduction and Development 81 735-747. (https://doi.org/10.1002/ mrd.22342)

Połeć A, Ráki M, Åbyholm T, Tanbo TG \& Fedorcsák P 2011 Interaction between granulosa-lutein cells and monocytes regulates secretion of angiogenic factors in vitro. Human Reproduction 26 2819-2829. (https://doi.org/10.1093/humrep/der216)

Practice Committee of the American Society for Reproductive Medicine 2015 Obesity and reproduction: a committee opinion. Fertility and Sterility 104 1116-1126. (https://doi.org/10.1016/j. fertnstert.2015.08.018)

Price JC, Bromfield JJ \& Sheldon IM 2013 Pathogen-associated molecular patterns initiate inflammation and perturb the endocrine function of bovine granulosa cells from ovarian dominant follicles via TLR2 and TLR4 pathways. Endocrinology 154 3377-3386. (https://doi. org/10.1210/en.2013-1102)

Ratchford AM, Chang AS, Chi MM-Y, Sheridan R \& Moley KH 2007 Maternal diabetes adversely affects AMP-activated protein kinase activity and cellular metabolism in murine oocytes. American Journal of Physiology: Endocrinology and Metabolism 293 E1198-E1206. (https:// doi.org/10.1152/ajpendo.00097.2007)

Ressler IB, Grayson BE, Ulrich-Lai YM \& Seeley RJ 2015 Diet-induced obesity exacerbates metabolic and behavioral effects of polycystic ovary syndrome in a rodent model. American Journal of Physiology: Endocrinology and Metabolism 308 E1076-E1084. (https://doi. org/10.1152/ajpendo.00182.2014)

Reynolds KA, Boudoures AL, Chi MM-Y, Wang Q \& Moley KH 2015 Adverse effects of obesity and/or high-fat diet on oocyte quality and metabolism are not reversible with resumption of regular diet in mice. Reproduction, Fertility and Development 27 716-724. (https://doi. org/10.1071/RD14251)

Rimessi A, Previati M, Nigro F, Wieckowski MR \& Pinton P 2016 Mitochondrial reactive oxygen species and inflammation: molecular mechanisms, diseases and promising therapies. International Journal of Biochemistry and Cell Biology 81 281-293. (https://doi.org/10.1016/j. biocel.2016.06.015)

Riva A, Borgo F, Lassandro C, Verduci E, Morace G, Borghi E \& Berry D 2017 Pediatric obesity is associated with an altered gut microbiota and discordant shifts in Firmicutes populations. Environmental Microbiology 19 95-105. (https://doi.org/10.1111/1462-2920.13463)

Rodgers RJ, Avery JC, Moore VM, Davies MJ, Azziz R, Stener-Victorin E, Moran LJ, Robertson SA, Stepto NK, Norman RJ et al. 2019 Complex diseases and co-morbidities: polycystic ovary syndrome and type 2 diabetes mellitus. Endocrine Connections 8 R71-R75. (https://doi. org/10.1530/EC-18-0502)

Ruebel M, Shankar K, Gaddy D, Lindsey F, Badger T \& Andres A 2016 Maternal obesity is associated with ovarian inflammation and upregulation of early growth response factor 1. American Journal of Physiology: Endocrinology and Metabolism 311 E269-E277. (https://doi. org/10.1152/ajpendo.00524.2015)

Ruebel ML, Cotter M, Sims CR, Moutos DM, Badger TM, Cleves MA, Shankar K \& Andres A 2017 Obesity modulates inflammation and lipidmetabolism oocyte gene expression: a single-cell transcriptome perspective. Journal of Clinical Endocrinology and Metabolism 102 2029-2038. (https://doi.org/10.1210/jc.2016-3524)

Saad MJ, Santos A \& Prada PO 2016 Linking gut microbiota and inflammation to obesity and insulin resistance. Physiology 31 283-293. (https://doi.org/10.1152/physiol.00041.2015)

Sapochnik M, Fuertes M \& Arzt E 2017 Programmed cell senescence: role of IL-6 in the pituitary. Journal of Molecular Endocrinology $\mathbf{5 8}$ R241-R253. (https://doi.org/10.1530/JME-17-0026)

Shao Y, Ding R, Xu B, Hua R, Shen Q, He K \& Yao Q 2017 Alterations of gut microbiota after Roux-en-Y gastric bypass and sleeve gastrectomy in Sprague-Dawley rats. Obesity Surgery 27 295-302. (https://doi. org/10.1007/s11695-016-2297-7)

Shimizu T, Kaji A, Murayama C, Magata F, Shirasuna K, Wakamiya K, Okuda K \& Miyamoto A 2012 Effects of interleukin-8 on estradiol and progesterone production by bovine granulosa cells from large follicles and progesterone production by luteinizing granulosa cells in culture. Cytokine 57 175-181. (https://doi.org/10.1016/j.cyto.2011.11.007)

Shimizu T, Imamura E, Magata F, Murayama C \& Miyamoto A 2013 Interleukin-8 stimulates progesterone production via the MEK pathway in ovarian theca cells. Molecular and Cellular Biochemistry 374 157-161. (https://doi.org/10.1007/s11010-012-1515-4)

Shimizu T, Ishizawa S, Magata F, Kobayashi M, Fricke PM \& Miyamoto A 2018 Involvement of lipopolysaccharide in ovarian cystic follicles in dairy cow: expressions of LPS receptors and steroidogenesis-related 
genes in follicular cells of cystic follicles. Animal Reproduction Science 195 89-95. (https://doi.org/10.1016/j.anireprosci.2018.05.010)

Skaznik-Wikiel ME, Swindle DC, Allshouse AA, Polotsky AJ \& McManaman JL 2016 High-Fat Diet Causes Subfertility and Compromised Ovarian Function Independent of Obesity in Mice. Biology of Reproduction 94 108. (https://doi.org/10.1095/biolreprod.115.137414)

Sokol CL \& Luster AD 2015 The chemokine system in innate immunity. Cold Spring Harbor Perspectives in Biology 7 1-20. (https://doi. org/10.1101/cshperspect.a016303)

Su YQ, Sugiura K, Woo Y, Wigglesworth K, Kamdar S, Affourtit J \& Eppig JJ 2007 Selective degradation of transcripts during meiotic maturation of mouse oocytes. Developmental Biology 302 104-117. (https://doi. org/10.1016/j.ydbio.2006.09.008)

Sutton-McDowall ML, Wu LLY, Purdey M, Goldys EM, Abell AD, MacMillan KL, Thompson JG \& Robker RL 2015 Nonesterified fatty acid-induced endoplasmic reticulum stress in cattle cumulus oocyte complexes alters cell metabolism and developmental competence. Biology of Reproduction 94 1-9.

Svoboda P, Franke V \& Schultz RM 2015 Sculpting the Transcriptome During the Oocyte-To-Embryo Transition in Mouse. Elsevier Inc.

Turnbaugh PJ, Ley RE, Mahowald MA, Magrini V, Mardis ER \& Gordon JI 2006 An obesity-associated gut microbiome with increased capacity for energy harvest. Nature 444 1027-1031. (https://doi.org/10.1038/ nature05414)

Turnbaugh PJ, Bäckhed F, Fulton L \& Gordon JI 2008 Diet-induced obesity is linked to marked but reversible alterations in the mouse distal gut microbiome. Cell Host and Microbe 3 213-223. (https://doi. org/10.1016/j.chom.2008.02.015)

Usta A, Avci E, Bulbul CB, Kadi H \& Adali E 2018 The monocyte counts to HDL cholesterol ratio in obese and lean patients with polycystic ovary syndrome. Reproductive Biology and Endocrinology 16 34. (https://doi. org/10.1186/s12958-018-0351-0)

Van Blerkom J 2011 Mitochondrial function in the human oocyte and embryo and their role in developmental competence. Mitochondrion 11 797-813. (https://doi.org/10.1016/j.mito.2010.09.012)

Van Blerkom J \& Davis P 2007 Mitochondrial signaling and fertilization. Molecular Human Reproduction 13 759-770. (https://doi.org/10.1093/ molehr/gam068)

Varfolomeev E \& Vucic D 2018 Intracellular regulation of TNF activity in health and disease. Cytokine 101 26-32. (https://doi.org/10.1016/j. cyto.2016.08.035)

Wang Y \& Huang F 2015 N-3 polyunsaturated fatty acids and inflammation in obesity: local effect and systemic benefit. BioMed Research International 2015 581469. (https://doi.org/10.1155/2015/581469)

Wang H, Wen Y, Polan ML, Boostanfar R, Feinman M \& Behr B 2005 Exogenous granulocyte-macrophage colony-stimulating factor promotes follicular development in the newborn rat in vivo. Human Reproduction 20 2749-2756. (https://doi.org/10.1093/humrep/dei123)

Wang Q, Ratchford AM, Chi MM-Y, Schoeller E, Frolova A, Schedl T \& Moley KH 2009 Maternal diabetes causes mitochondrial dysfunction and meiotic defects in murine oocytes. Molecular Endocrinology 23 1603-1612. (https://doi.org/10.1210/me.2009-0033)

Wang YC, McPherson K, Marsh T, Gortmaker SL \& Brown M 2011 Health and economic burden of the projected obesity trends in the USA and the UK. Lancet 378 815-825. (https://doi.org/10.1016/S01406736(11)60814-3)

Wang N, Luo LL, Xu JJ, Xu MY, Zhang XM, Zhou XL, Liu WJ \& Fu YC 2014 Obesity accelerates ovarian follicle development and follicle loss in rats. Metabolism 63 94-103. (https://doi.org/10.1016/j. metabol.2013.09.001)
Wang H, Cheng Q, Li X, Hu F, Han L, Zhang H, Li L, Ge J, Ying X, Guo X et al. 2018 Loss of TIGAR induces oxidative stress and meiotic defects in oocytes from obese mice. Molecular and Cellular Proteomics $\mathbf{1 7}$ 1354-1364. (https://doi.org/10.1074/mcp.RA118.000620)

Wood JR, Dumesic DA, Abbott DH \& Strauss JF 2007 Molecular abnormalities in oocytes from women with polycystic ovary syndrome revealed by microarray analysis. Journal of Clinical Endocrinology and Metabolism 92 705-713. (https://doi.org/10.1210/jc.2006-2123)

Wu R, Fujii S, Sini I, Van der Hoek KH, Jasper MJ, Ryan NK, Robker RL, Robertson SA \& Norman RJ 2006 Ovarian leukocyte distribution and cytokine/chemokine mRNA expression in follicular fluid cells in women with polycystic ovary syndrome. Human Reproduction 22 527-535.

Wu LLY, Dunning KR, Yang X, Russell DL, Lane M, Norman RJ \& Robker RL 2010 High-fat diet causes lipotoxicity responses in cumulus-oocyte complexes and decreased fertilization rates. Endocrinology 151 5438-5445. (https://doi.org/10.1210/en.2010-0551)

Wu LL, Russell DL, Norman RJ \& Robker RL 2012 Endoplasmic reticulum (ER) stress in cumulus-oocyte complexes impairs Pentraxin-3 secretion, mitochondrial membrane potential $(\Delta \Psi \mathrm{m})$, and embryo development. Molecular Endocrinology 26 562-573. (https://doi.org/10.1210/me.20111362)

Wu LL, Russell DL, Wong SL, Chen M, Tsai TS, St John JC, Norman RJ, Febbraio MA, Carroll J \& Robker RL 2015 Mitochondrial dysfunction in oocytes of obese mothers: transmission to offspring and reversal by pharmacological endoplasmic reticulum stress inhibitors. Development 142 681-691. (https://doi.org/10.1242/dev.114850)

Xie F, Anderson CL, Timme KR, Kurz SG, Fernando SC \& Wood JR 2016 Obesity-dependent increases in oocyte mRNAs are associated with increases in proinflammatory signaling and gut microbial abundance of Lachnospiraceae in female mice. Endocrinology 157 1630-1643. (https://doi.org/10.1210/en.2015-1851)

Yang X, Wu LL, Chura LR, Liang X, Lane M, Norman RJ \& Robker RL 2012 Exposure to lipid-rich follicular fluid is associated with endoplasmic reticulum stress and impaired oocyte maturation in cumulusoocyte complexes. Fertility and Sterility 97 1438-1443. (https://doi. org/10.1016/j.fertnstert.2012.02.034)

Yin J, Duan J, Cui Z, Ren W, Li T \& Yin Y 2015 Hydrogen peroxideinduced oxidative stress activates NF- $\mathrm{kB}$ and Nrf2/Keap1 signals and triggers autophagy in piglets. RSC Advances 5 15479-15486. (https:// doi.org/10.1039/C4RA13557A)

Zhang Z, Fang Q \& Wang J 2008 Involvement of macrophage colonystimulating factor (M-CSF) in the function of follicular granulosa cells. Fertility and Sterility 90 749-754. (https://doi.org/10.1016/j. fertnstert.2007.06.098)

Zhang L, Hou X, Ma R, Moley K, Schedl T \& Wang Q 2014 Sirt2 functions in spindle organization and chromosome alignment in mouse oocyte meiosis. FASEB Journal 28 1435-1445. (https://doi.org/10.1096/fj.13244111)

Zhang L, Han L, Ma R, Hou X, Yu Y, Sun S, Xu Y, Schedl T, Moley KH \& Wang Q 2015 Sirt3 prevents maternal obesity-associated oxidative stress and meiotic defects in mouse oocytes. Cell Cycle 14 2959-2968. (https:// doi.org/10.1080/15384101.2015.1026517)

Received 11 November 2018

First decision 17 December 2018

Revised manuscript received 12 April 2019

Accepted 18 April 2019 